\title{
Assessing sulfate reduction and methane cycling in a high salinity pore water system in the northern Gulf of Mexico
}

\author{
J.W. Pohlman ${ }^{\mathrm{a}, *}$, C. Ruppel ${ }^{\mathrm{a}}$, D.R. Hutchinson ${ }^{\mathrm{a}}$, R. Downer ${ }^{\mathrm{b}}$, R.B. Coffin ${ }^{\mathrm{c}}$ \\ ${ }^{\text {a } U . S . ~ G e o l o g i c a l ~ S u r v e y, ~ W o o d s ~ H o l e ~ S c i e n c e ~ C e n t e r, ~} 384$ Woods Hole Road, Woods Hole, MA 02543, USA \\ ${ }^{\mathrm{b}}$ Milbar Hydrotest, Shreveport LA, USA \\ ${ }^{\mathrm{c}}$ Naval Research Laboratory, Washington DC, USA
}

\section{A R T I C L E I N F O}

\section{Article history:}

Received 28 August 2007

Received in revised form 10 October 2007

Accepted 8 January 2008

\section{Keywords:}

Gas hydrate

Methane

Anaerobic methane oxidation

Sulfate

Brine

Gulf of Mexico

\begin{abstract}
A B S T R A C T
Pore waters extracted from 18 piston cores obtained on and near a salt-cored bathymetric high in Keathley Canyon lease block 151 in the northern Gulf of Mexico contain elevated concentrations of chloride (up to $838 \mathrm{mM}$ ) and have pore water chemical concentration profiles that exhibit extensive departures (concavity) from steady-state (linear) diffusive equilibrium with depth. Minimum $\delta^{13} \mathrm{C}$ dissolved inorganic carbon (DIC) values of $-55.9 \%$ to $-64.8 \%$ at the sulfate-methane transition (SMT) strongly suggest active anaerobic oxidation of methane (AOM) throughout the study region. However, the nonlinear pore water chemistrydepth profiles make it impossible to determine the vertical extent of active AOM or the potential role of alternate sulfate reduction pathways. Here we utilize the conservative (non-reactive) nature of dissolved chloride to differentiate the effects of biogeochemical activity (e.g., AOM and/or organoclastic sulfate reduction) relative to physical mixing in high salinity Keathley Canyon sediments. In most cases, the DIC and sulfate concentrations in pore waters are consistent with a conservative mixing model that uses chloride concentrations at the seafloor and the SMT as endmembers. Conservative mixing of pore water constituents implies that an undetermined physical process is primarily responsible for the nonlinearity of the pore water-depth profiles. In limited cases where the sulfate and DIC concentrations deviated from conservative mixing between the seafloor and SMT, the $\delta^{13} \mathrm{C}$-DIC mixing diagrams suggest that the excess DIC is produced from a ${ }^{13} \mathrm{C}$-depleted source that could only be accounted for by microbial methane, the dominant form of methane identified during this study. We conclude that AOM is the most prevalent sink for sulfate and that it occurs primarily at the SMT at this Keathley Canyon site.
\end{abstract}

Published by Elsevier Ltd.

\section{Introduction}

Hydrocarbons and brines from deep reservoirs in the northern Gulf of Mexico migrate to the seafloor along faults and conduits that are often genetically related to salt-driven tectonics and release of overpressures (Bouma and Roberts, 1990). Seafloor manifestations of the discharge of gas and hydrocarbon-rich fluids include widespread cold seeps, brine pools, mud volcanoes and gas hydrate mounds, often associated with chemosynthetic communities (MacDonald et al., 1996; Roberts et al., 1990; Roberts and Carney, 1997; Sager et al., 2004). Although poorly constrained (e.g., Whelan et al., 2005), the transmission of hydrocarbons (primarily methane) from the sediments to the water column and possibly the atmosphere (MacDonald et al., 2002) is of great interest owing to the potency of methane as a greenhouse gas. Compared to other continental margin settings, hydrocarbon flux at the seafloor may be particularly enhanced in the Gulf of Mexico (MacDonald et al., 1993;

\footnotetext{
* Corresponding author. Tel.: +1508 4572213.

E-mail address: jpohlman@usgs.gov (J.W. Pohlman).
}

MacDonald et al., 1996). Gas hydrate has been hypothesized to sequester large quantities of hydrocarbons in the northern Gulf of Mexico (Sassen et al., 2001), but elevated salinity and locally increased temperatures in some locations reduce the capacity for hydrocarbon capture in gas hydrate deposits (Paull et al., 2005; Ruppel et al., 2005).

Offsetting the potential impact of seafloor methane emissions is the anaerobic oxidation of methane (AOM) in the shallow sedimentary section (Hinrichs and Boetius, 2002; Niemann et al., 2006). AOM is mediated by a consortium of archaea and sulfate reducing bacteria within the sulfate-methane transition (SMT) (Hoehler et al., 1994; Boetius et al., 2000; Valentine and Reeburgh, 2000; Orphan et al., 2001; Niemann et al., 2006) according to:

$\mathrm{CH}_{4}+\mathrm{SO}_{4}^{-2} \rightarrow \mathrm{HCO}_{3}^{-}+\mathrm{HS}^{-}+\mathrm{H}_{2} \mathrm{O}$.

The availability of sulfate for AOM, and hence its capacity to consume methane, is limited by sulfate transport from the overlying seawater and competition for that sulfate among microbes utilizing different sulfate reduction (SR) pathways (Niemann et al., 2006). In some settings, methane is the dominant substrate for SR 
(Niewohner et al., 1998; Boetius et al., 2000). Studies in other areas, including northern Gulf of Mexico hydrocarbon seeps (Joye et al., 2004; Kniemeyer et al., 2007), Hydrate Ridge offshore Oregon (Claypool et al., 2006), and the Guaymas basin in the Gulf of California (Kniemeyer et al., 2007), suggest that oxidation of organic compounds other than methane (i.e., organoclastic SR) is the primary sulfate sink. These conclusions are based on measured rates of AOM and SR, diagenetic modeling, and incubation studies. Understanding the fate of sulfate in methane-charged sediments is critical for predicting the effectiveness of the AOM biofilter in preventing methane from reaching the overlying ocean and possibly the atmosphere.

In this study, we determine the pathways (organoclastic SR v. AOM) and spatial occurrence of SR in near-seafloor sediments with high pore water salinity and distinctively nonlinear pore water concentration-depth profiles recovered from the Keathley Canyon area of the northern Gulf of Mexico. Adopting an approach that has been applied to differentiate the effects of physical mixing and biogeochemical alterations along estuarine salinity gradients (Cifuentes and Eldridge, 1998; Chanton and Lewis, 1999; Coffin and Cifuentes, 1999; Kaldy et al., 2005), we evaluate deviations from conservative mixing between the seafloor and the SMT for sulfate and DIC. The results lead to a robust biogeochemical assessment of the role of anaerobic cycling of organic matter in the near-surface sediments of Keathley Canyon.

\section{Methods}

\subsection{Site description and core collection}

The study site is located within the salt tectonics province of the northern Gulf of Mexico (inset, Fig. 1). The continental slope in the northern Gulf is bounded on the north by the shelf break and on the south by the Sigsbee Escarpment. During Plio-Pleistocene times, deeply buried Jurassic-age salt was mobilized as the result of sediment loading that accompanied the shifting position of the ancestral Mississippi River. The salt mobilized to form structural highs and adjacent salt withdrawal minibasins, thereby imparting an irregular bathymetry on the seafloor (Peel et al., 1995).

The cores were collected along the southeast edge of the Casey minibasin and the adjacent structural high in water depths of 1230-1455 m (Fig. 1, Table 1) during a cruise aboard the R/V Gyre in August 2003. The core sites were chosen from multichannel seismic profiles (Hutchinson and Hart, 2004) displaying a bottom simulating reflection (BSR). The BSR has been mapped along the southeast portion of the Casey Basin and beneath a 2-km wide, 80$m$ high seafloor mound - the Alpha mound - located on the adjacent structural high (Hutchinson et al., in press). The Alpha mound may be intensely faulted because of its location at the intersection of three structural highs along the edges of nearby minibasins. The core sites were laid out in three transects across the Alpha mound, along seismic reflection profiles KC01, KC11 and KC57 (Fig. 1). Two smaller mounds near the Alpha mound have been interpreted as potential localized seep sites, although it is uncertain if they are currently active (Hutchinson et al., in press).

The Joint Industry Project (JIP) Keathley Canyon drill site that is discussed elsewhere (e.g., Kastner et al., 2008) is $\sim 3 \mathrm{~km}$ northwest of the Alpha mound on the eastern edge of the Casey minibasin (Fig. 1). Hutchinson et al. (in press, 2008) provide a detailed geological framework for the Keathley Canyon area and describe the features and geologic structures that occur near the JIP drill site.

\subsection{Core processing}

A total of 247, 10-cm-long, whole round sections from 18 piston cores up to $6 \mathrm{~m}$ long were cut at a spacing of $\sim 25 \mathrm{~cm}$. Sampling was more frequent near the SMT, which was identified visually by a color transition and proximity to the first gas expansion cracks.

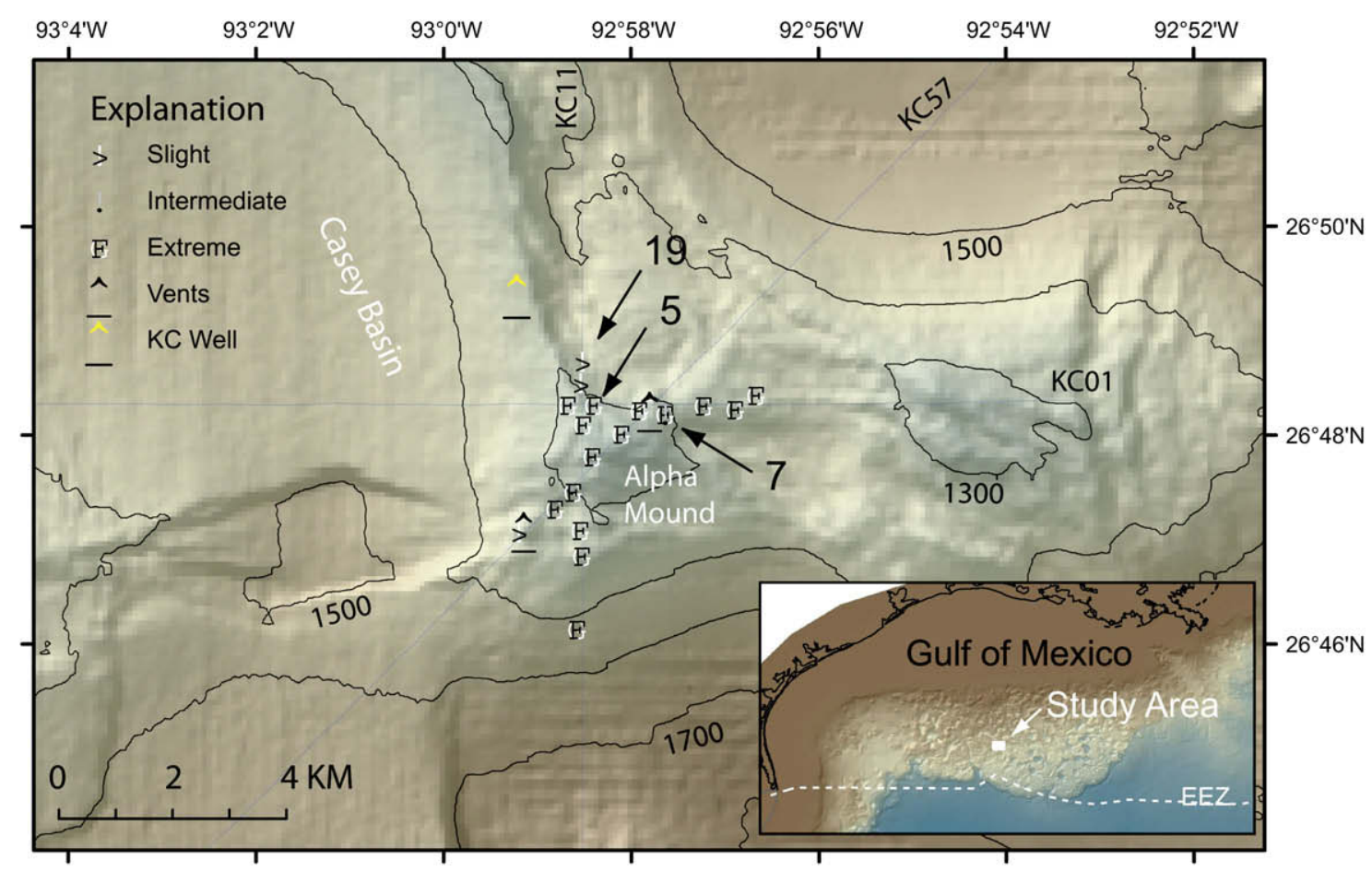

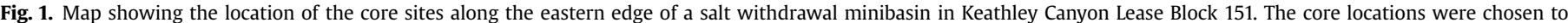

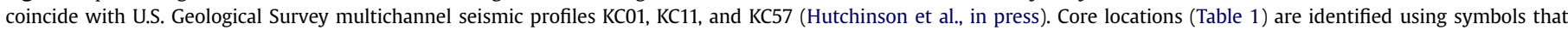

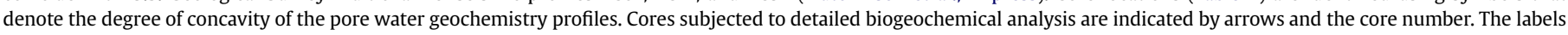

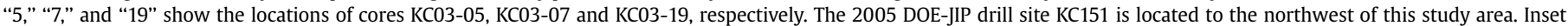
shows the location of the study area within the context of the minibasin province of the northern Gulf of Mexico. 
Table 1

Core descriptions

\begin{tabular}{llllll}
\hline Core ID & Longitude & Latitude & Concavity ${ }^{\mathrm{a}}$ & $\begin{array}{l}\text { Water } \\
\text { depth }(\mathrm{m})\end{array}$ & $\begin{array}{l}\text { Core } \\
\text { length }(\mathrm{cm})\end{array}$ \\
\hline KC03-01 & $26^{\circ} 48.2636$ & $92^{\circ} 56.8735$ & Extreme & 1340 & 445 \\
KC03-02 & $26^{\circ} 48.2998$ & $92^{\circ} 56.6521$ & Extreme & 1455 & 484 \\
KC03-03 & $26^{\circ} 48.3012$ & $95^{\circ} 57.2131$ & Extreme & 1430 & 478 \\
KC03-05 & $26^{\circ} 48.305$ & $92^{\circ} 58.382$ & Extreme & 1297 & 466 \\
KC03-06 & $26^{\circ} 48.306$ & $92^{\circ} 58.663$ & Extreme & 1280 & 493 \\
KC03-07 & $26^{\circ} 48.215$ & $92^{\circ} 57.615$ & Moderate & 1302 & 491 \\
KC03-08 & $26^{\circ} 48.523$ & $92^{\circ} 58.523$ & Slight & 1300 & 325 \\
KC03-09 & $26^{\circ} 48.1163$ & $92^{\circ} 58.4992$ & Extreme & 1240 & 555 \\
KC03-10 & $26^{\circ} 47.4729$ & $92^{\circ} 58.6012$ & Extreme & 1280 & 573 \\
KC03-11 & $26^{\circ} 47.1044$ & $92^{\circ} 58.5243$ & Extreme & 1302 & 547 \\
KC03-12 & $26^{\circ} 46.8604$ & $92^{\circ} 58.5116$ & Extreme & 1314 & 553 \\
KC03-13 & $26^{\circ} 46.158$ & $92^{\circ} 58.562$ & Extreme & 1380 & 596 \\
KC03-14 & $26^{\circ} 47.091$ & $92^{\circ} 59.182$ & Slight & 1360 & 391 \\
KC03-15 & $26^{\circ} 47.381$ & $92^{\circ} 58.794$ & Extreme & 1312 & 609 \\
KC03-16 & $26^{\circ} 47.813$ & $92^{\circ} 58.400$ & Extreme & 1255 & 511 \\
KC03-17 & $26^{\circ} 48.0294$ & $92^{\circ} 58.0893$ & Extreme & 1230 & 537 \\
KC03-18 & $26^{\circ} 48.255$ & $92^{\circ} 57.895$ & Extreme & 1273 & 508 \\
KC03-19 & $26^{\circ} 48.727$ & $92^{\circ} 58.506$ & Slight & 1340 & 621 \\
\hline
\end{tabular}

${ }^{a}$ See text for description of concavity.

Headspace gas samples were collected as $2 \mathrm{ml}$ plugs from the top of each whole round and transferred into pre-weighed $20 \mathrm{ml}$ serum vials (Hoehler et al., 2000). Some gas expansion voids below the SMT were sampled by piercing the clear core liner and collecting with airtight $60 \mathrm{ml}$ plastic syringes fitted with a stopcock and syringe adapter. The void gas samples were transferred via $1 / 8^{\prime \prime}$ silicon tubing into $20 \mathrm{ml}$ serum vials that were inverted and submerged in deionized water. The headspace and void gas vials were sealed with $1 \mathrm{~cm}$ thick septa and stored at $-20^{\circ} \mathrm{C}$.

Whole round sediment sections were capped and transported to the shipboard laboratory for pore water extraction. To avoid contamination by seawater, exposed surfaces were scraped away, leaving only the center of each whole round. Sediments were repacked into pressure filtration squeezers, and pore waters were extracted into air-tight $60 \mathrm{ml}$ plastic syringes by applying a nitrogen headspace pressure of $\sim 5$ bar to a latex sheet separating the sample from the headspace gas (Reeburgh, 1967). Pore water samples ( $\sim 20-25 \mathrm{ml}$ ) were filtered through $0.2 \mu \mathrm{m}$ Acrodisc PES syringe filters (Pall Corporation) into oven-baked $\left(450{ }^{\circ} \mathrm{C}, 4 \mathrm{~h}\right)$ scintillation vials and were subsequently dispensed into storage containers appropriate to the specific analysis. The time between core recovery and sample storage at $-20^{\circ} \mathrm{C}$ was $\sim 2 \mathrm{~h}$.

\subsection{Shipboard laboratory analyses}

The headspace concentration of hydrocarbon $\left(C_{1}-C_{3}\right)$ gases and the pore water concentrations of dissolved inorganic carbon (DIC), sulfate, chloride, and total dissolved sulfide were measured shipboard. The headspace hydrocarbon concentrations were determined using a Shimadzu 14-A gas chromatograph (GC) equipped with a flame ionization detector (FID). The gases were isothermally $\left(50^{\circ} \mathrm{C}\right)$ separated with a Poraplot-Q stainless steel column ( $8 \mathrm{ft}, 1 / 8^{\prime \prime} \mathrm{OD}$ ) packed with $60 / 80$ mesh and quantified against certified gas standards. Headspace concentrations were converted to aqueous concentrations using the method of Hoehler et al. (2000). The porosity (as \% water volume) was measured from the sediment plugs of three focus cores by weighing the vials before and after sediments were dried at $50^{\circ} \mathrm{C}$ for 2-3 days. The linear regression of porosity and depth from those cores $\left(r^{2}=0.55\right)$ was used to estimate the depth-specific porosity for the 16 remaining piston cores. Porosity values ranged from 0.75 at the seafloor to 0.57 at the base of the focus cores.

Pore water sulfate and chloride concentrations were determined using a Dionex DX-120 ion chromatograph (IC) equipped with a $4 \mathrm{~mm}$ AS-9HC column and an AS-40 autosampler following the method of Paull et al. (2005), but with sample dilution of 1:50. Peak areas for sulfate and chloride were quantified against equivalently diluted International Association for the Physical Sciences of the Oceans (IAPSO) standard seawater analyzed at the beginning of the run and after every fifth sample. The analytical precision for dissolved sulfate was $\pm 1 \%$ of the IAPSO standard values, which are $28.9 \mathrm{mM}$ for sulfate and $559 \mathrm{mM}$ for chloride.

Pore water DIC concentrations were determined with a model 5011 UIC coulometer and quantified relative to a seawater certified reference material (CRM). One $\mathrm{ml}$ of $10 \%$ phosphoric acid saturated with $\mathrm{CuSO}_{4}$ was added to the vials containing a $3 \mathrm{ml}$ sample to convert the DIC to $\mathrm{CO}_{2}$ and precipitate dissolved sulfides as $\mathrm{CuS}$ (Boehme et al., 1996). The $\mathrm{CO}_{2}$ was transferred to the coulometer with a purified He carrier gas and was measured with an analytical precision of $\pm 1 \%$ of the CRM $(\sim 2.2 \mathrm{mM})$.

Total dissolved sulfides were determined spectrophotometrically $(670 \mathrm{~nm})$ using a modification of the Cline method (Cline, 1969). A $0.12 \mathrm{M}$ solution of Cline reagent was prepared less than one week before the cruise. Separate standard curves were prepared for low $(0-2 \mathrm{mM})$ and high $(2-25 \mathrm{mM})$ concentration samples. Low concentration samples were diluted 1:2 with the Cline reagent, while high concentration samples were diluted 1:10 to ensure that the reagent was present in excess quantity. The entire low concentration sample mix $(2 \mathrm{ml})$ and $20 \%$ of the high concentration sample mix $(10 \mathrm{ml})$ was diluted to $50 \mathrm{ml}$ with deionized water before spectrophotometric determination with an analytical precision of $\pm 10 \%$.

\subsection{Stable carbon isotope analysis}

The stable carbon isotope composition of methane from the headspace of the serum vials was determined using a Thermo Electron Trace gas chromatograph (GC) modified with a dualcryogenic focusing inlet and a Finnigan Delta Plus XP isotope ratio mass spectrometer (IRMS) with high resistivity amplifiers (Plummer et al., 2005). Variable volume $(0.02-15.0 \mathrm{ml})$ gas samples containing at least $10 \mathrm{ng}$ of methane carbon were injected into an $8 \mathrm{ml} \mathrm{min}{ }^{-1}$ He carrier stream. Following initial cryofocusing onto a $1 / 4^{\prime \prime}$ stainless steel Poraplot-Q loop immersed in liquid nitrogen $\left(\mathrm{LN}_{2}\right)$, the methane was refocused with $\mathrm{LN}_{2}$ at the head of the column in a small section of fused silica capillary packed with 80/ 100 mesh Poraplot-Q. Dual focusing was required for the larger volume injections $(>2 \mathrm{ml})$ to reduce the transfer of atmospheric nitrogen to the GC column. After reducing the He carrier flow to $1.6 \mathrm{ml} \mathrm{min}{ }^{-1}$, methane was rapidly desorbed $\left(100^{\circ} \mathrm{C}\right)$ and separated at $-10^{\circ} \mathrm{C}$ on a Poraplot-Q column ( $25 \mathrm{~m}, 0.32 \mathrm{~mm}$ ID), oxidized to $\mathrm{CO}_{2}$ with a GCC-III interface (Thermo-Electron), and analyzed by IRMS. Sub-ambient cooling was necessary to separate the methane from residual nitrogen.

The ${ }^{13} \mathrm{C} /{ }^{12} \mathrm{C}$ ratios for methane are expressed in the standard $\delta$ notation using tank $\mathrm{CO}_{2}$ referenced to the NIST RM 8560 natural gas standard. The $\delta^{13} \mathrm{C}-\mathrm{CH}_{4}$ values reported here reflect mass balance corrections for atmospheric methane ( $1.7 \mathrm{ppmv},-45 \%$ ) in the vials. The analytical precision (obtained by triplicate analyses of every tenth sample) was better than $0.5 \%$.

The stable carbon isotope composition $\left({ }^{13} \mathrm{C} /{ }^{12} \mathrm{C}\right)$ of pore water DIC was measured using a Thermo Finnigan Delta S IRMS. Twohundred microliters of $85 \%$ phosphoric acid saturated with $\mathrm{CuSO}_{4}$ was added to a $3 \mathrm{ml}$ sample vial with a headspace of less than $0.5 \mathrm{ml}$. The samples were shaken vigorously at least once every $15 \mathrm{~min}$ for $2 \mathrm{~h}$ to allow the DIC to transfer into the headspace as $\mathrm{CO}_{2}$. Headspace gas from the sample vial was then injected into the GC, where the $\mathrm{CO}_{2}$ was separated isothermally $\left(50^{\circ} \mathrm{C}\right)$ on a Poraplot-Q capillary column $(30 \mathrm{~m}, 0.32 \mathrm{~mm}$ ID). Values are reported relative to the VPBD standard in the standard $\delta$ notation. The analytical precision for $\delta^{13} \mathrm{C}$-DIC was $\pm 1 \%$ \% 


\section{Results}

\subsection{Profile shapes and general patterns}

Among the 18 cores evaluated, the chloride and sulfate pore water concentration-depth-profiles exhibited a wide range of concavity (i.e., nonlinearity) as shown in Fig. 2a and b. These examples are representative of the degree to which the pore water geochemistry for the entire data set deviates from linear, diffusive profiles. To differentiate the profile shapes among all of the analytes the cores were separated into three visually distinct groups (Fig. 2, Table 1): (1) extreme concavity (14 cores); (2) moderate concavity (one core); and (3) slight concavity (three cores).

Sulfate concentrations range from near-seawater $(28.1 \mathrm{mM} \pm 0.5)$ values at the seafloor to values at or near the limits of detection $(0.1 \mathrm{mM})$ at depth (Fig. 2a). Cores with pore water profiles designated as extremely concave maintain near-seawater sulfate (26.0-27.7 mM) in the upper $2 \mathrm{~m}$ before the concentrations decrease with greater depth. For the other profile groups, near-seawater concentrations are not maintained below the depth of the shallowest sample. The maximum depth of sulfate penetration generally occurs at greater sediment depths in the cores with extreme concavity (SMT at $\sim 4.3$ to $5.5 \mathrm{mbsf}$ ) than those with less concavity (SMT at $\sim 2.9$ to $4.6 \mathrm{mbsf}$ ).

Chloride concentrations increase from seawater values near the seafloor $(552 \mathrm{mM} \pm 5)$ to values as high as $838 \mathrm{mM}$ at depth (Fig. 2b). Near-seawater chloride concentrations (544-566 mM) are maintained in the upper $2 \mathrm{~m}$ from cores with extreme concavity. Cores with slight concavity have greater maximum chloride concentrations (769-838 mM) than the other cores (544-684 mM). We recorded no chloride concentrations appreciably lower than those in seawater or deviating significantly from the trend of the measured concentration profiles, implying that gas hydrate, which
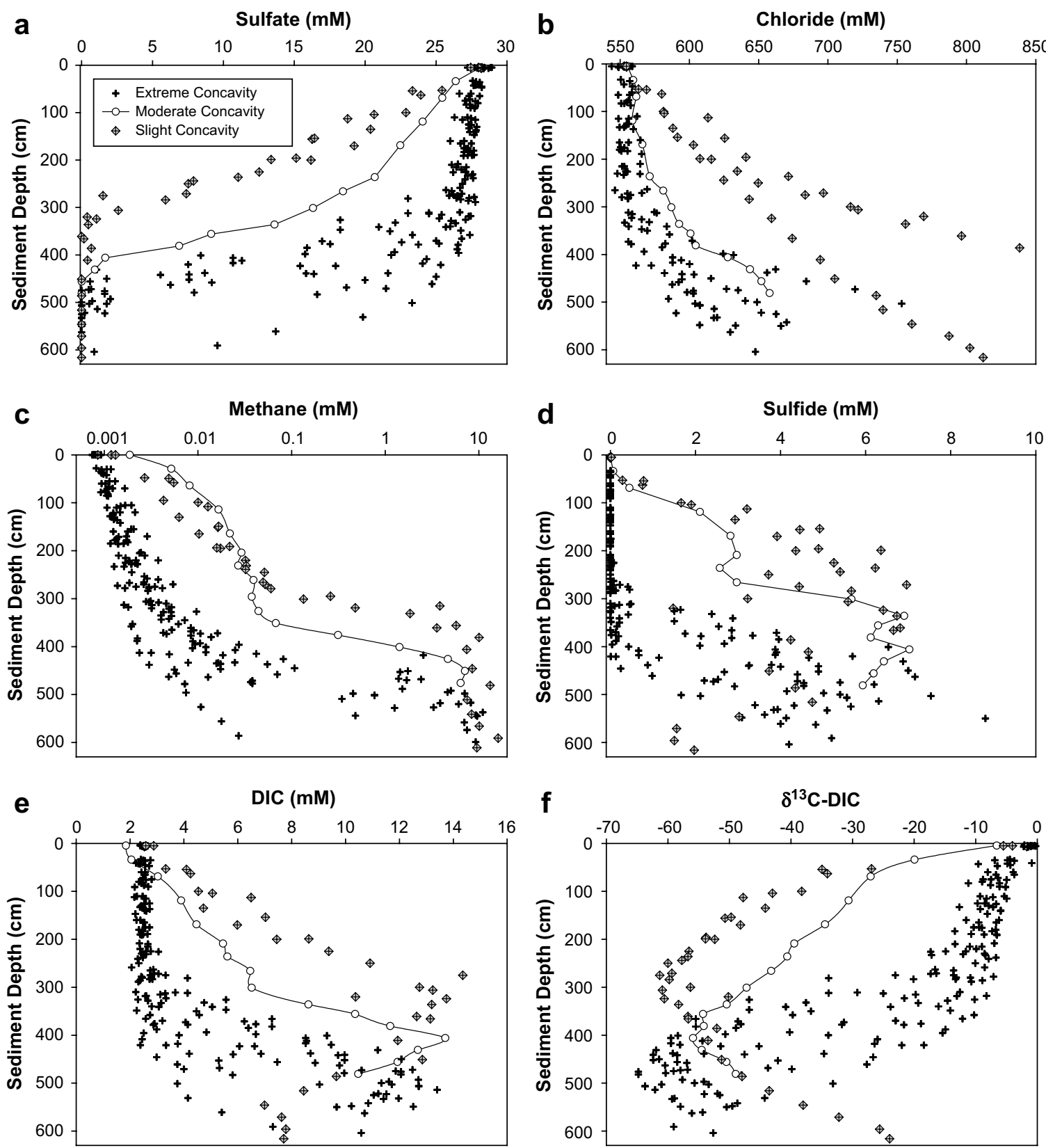

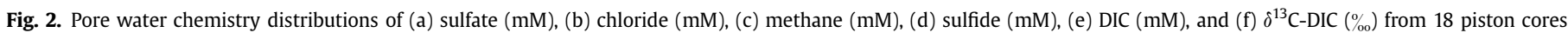

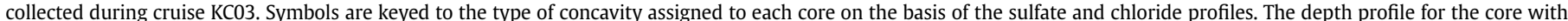
moderate concavity (KCO3-07) is provided as a visual aid for differentiating the unique distribution of the extremely concave core data and the slightly concave core data. 
freshens pore waters upon dissociation, was probably absent insitu over the depth range of the cores.

Methane concentrations at the sediment-water interface for all cores are between 0.001 and $0.002 \mathrm{mM}$ (Fig. 2c). Within the upper $2 \mathrm{~m}$, the concentrations of dissolved methane from cores with extremely concave sulfate and chloride profiles are lower than those with moderate and slightly concave profiles. Maximum methane concentrations (7-16 mM) for all cores occur at depths where sulfate is depleted (Fig. 2a). However, the maximum measured methane concentrations most likely underestimate the in-situ concentrations. Because the saturation concentration of methane at atmospheric pressure is $\sim 1.8 \mathrm{mM}$ (Yamamoto et al., 1976), we expect considerable loss of dissolved phase methane from pore waters with measured concentrations exceeding this value.

Total dissolved sulfide is below detection $(<0.1 \mathrm{mM})$ in the upper $2 \mathrm{~m}$ of the cores with extreme concavity (Fig. 2d) and less than $0.4 \mathrm{mM}$ between 2 and $3 \mathrm{mbsf}$. Deeper than $3 \mathrm{mbsf}$, the sulfide concentrations increase to a maximum of $8.8 \mathrm{mM}$. With the exception of the seafloor samples, sulfide is present throughout the cores having moderate and slightly concave pore water concentration profiles, Maximum sulfide concentrations for these cores is 5.3-7.0 mM.

The DIC concentrations $(2.4-2.7 \mathrm{mM})$ and $\delta^{13} \mathrm{C}$ values $(+0.2 \%$ to $-13.4 \%$ ) in the upper $2 \mathrm{~m}$ of the cores with extreme concavity are slightly altered with respect to seawater $(2.3 \mathrm{mM}$ and $0 \%$ ) and distinct from the other profile shape types (moderate and slight concavity) (Fig. 2e and f). However, all profile categories have similar DIC concentration maxima of $14-15 \mathrm{mM}$ and $\delta^{13} \mathrm{C}$ minima of $-55.9 \%$ to $-64.8 \%$. With increasing depth below the DIC concentration maxima and $\delta^{13} \mathrm{C}$-DIC minima for each category, the DIC concentrations decrease and the $\delta^{13} \mathrm{C}$ values increase, respectively.

\subsection{Core specific profiles}

To assess variations among biogeochemically reactive pore water constituents (methane, sulfate, DIC), we select three focus cores qualitatively characterized by extreme (Core KC03-05), moderate (KCO3-07), and slight (KC03-19) concavity in Fig. 2. The corresponding pore water geochemical data are shown in Fig. 3. Sulfate depletion, a sudden change in methane concentration, the DIC concentration maxima, and the $\delta^{13} \mathrm{C}_{-} \mathrm{CH}_{4}$ minima coincide with and delineate the depth of the SMT. Methane concentrations within the SMT of the three cores range from 0.1 to $1.0 \mathrm{mM}$, DIC concentrations range from 11.2 to $13.8 \mathrm{mM}$, sulfate concentrations range from 0.5 to $1.7 \mathrm{mM}$, and methane $\delta^{13} \mathrm{C}$ values range from $-90.2 \%$ to $-106.5 \%$ (Fig. 3). The $\delta^{13} \mathrm{C}$ of both methane and DIC increases with distance (above and below) from the SMT.

\subsection{Void gas concentrations and stable carbon isotope signatures}

As shown in Table 2, void gas samples are almost entirely (99.98-99.99\%) methane. The average $\delta^{13} \mathrm{C}$ of the methane is $-75.2 \% \pm 1.3(n=4)$, which is within the range reported from deeper cores recovered at the nearby the JIP Keathley Canyon drill sites (Lorenson et al., 2008).

\section{Discussion}

\subsection{Microbial methanogenesis and AOM}

Faulting related to salt tectonism provides the primary conduits for mostly vertical migration and expulsion of hydrocarbons from the deep subsurface petroleum system of the northern Gulf of Mexico (Bouma and Roberts, 1990). Both thermogenic and microbial gas sources have been reported in the Gulf of Mexico based on studies of gases venting at seafloor seeps and sequestered in gas hydrate (Brooks et al., 1984; Sassen et al., 2003; Milkov, 2005 and references therein; Lorenson et al., 2008). Distinguishing the origin of the gases is important because the type of gas (methane dominated microbial vs. mixtures of thermogenic gases) influences gas hydrate stability conditions (Sloan, 1998) and constrains the active biogeochemical cycles (Orcutt et al., 2005; Joye et al., 2004). In the shallow sediments at Keathley Canyon, $C_{1} /\left[C_{2}+C_{3}\right]$ ratios $(\sim 5700$ to 7200 ) and $\delta^{13} \mathrm{C}$ values of methane from below the SMT $(-75.2 \% \pm 1.3)$ (Table 2 ) suggests a predominantly microbial methane source (Whiticar, 1999), which is consistent with the conclusion obtained from a detailed analysis of the deeper gas hydrate system (Lorenson et al., 2008).

Several lines of evidence suggest that the microbial methane supported AOM within the SMT of this setting (Fig. 3): (1) methane concentrations decrease from maximum values of 7-16 mM below the SMT to less than $0.3 \mathrm{mM}$ just above the SMT, indicating methane consumption within the SMT; (2) sulfate concentrations are less than $0.2 \mathrm{mM}$ within the SMT, which is consistent with sulfate reduction by AOM; (3) the coincidence of the DIC concentration maxima (14-15 $\mathrm{mM}$ ) with the SMT suggests DIC production by AOM; and (4) $\delta^{13} \mathrm{C}$-DIC at the SMT $\left(-65 \%\right.$ to $-68 \%$ ) is more ${ }^{13} \mathrm{C}$ depleted than is possible if the DIC originated from oxidation of hydrocarbons or sediment organic matter. The only plausible source for this ${ }^{13} \mathrm{C}$-depleted DIC is ${ }^{13} \mathrm{C}$-depleted microbial methane (Claypool and Kaplan, 1974; Blair and Aller, 1995).

The methane stable carbon isotope data further imply that AOM is coupled with methanogenesis within the SMT (Borowski et al., 1997; Paull et al., 2000). During carbonate reduction, which is the dominant methanogenic pathway in marine systems, ${ }^{13} \mathrm{C}$-depleted DIC (occurring as bicarbonate, $\mathrm{HCO}_{3}^{-}$) is preferentially reduced to methane via:

$4 \mathrm{H}_{2}+\mathrm{HCO}_{3}^{-}+\mathrm{H}^{+} \rightarrow \mathrm{CH}_{4}+3 \mathrm{H}_{2} \mathrm{O}$.

Isotopic fractionation during methanogenesis produces methane with a $\delta^{13} \mathrm{C}$ value that is ${ }^{13} \mathrm{C}$-depleted by $55-65 \%$ (Whiticar, 1999; Claypool and Threlkeld, 1983) relative to the bicarbonate source. To achieve the minimum $\delta^{13} \mathrm{C}_{-} \mathrm{CH}_{4}$ values measured at the SMT in this study $(-90.2 \%$ to $-106.5 \%$; Fig. $3 a-c)$ requires a DIC source for methanogenesis that is at least partially derived from AOM, thus indicating that methanogenesis and AOM are coupled and active within the SMT.

\subsection{Mechanisms that control sulfate-depth profiles}

A linear sulfate-depth profile between the sediment-water interface and the SMT is evidence that AOM is the dominant sulfate sink (Borowski et al., 1996; Niewohner et al., 1998; Dickens, 2001). This approach assumes that the downward diffusive flux of sulfate is balanced by an upward flux of methane and that AOM (Eq. (1)) consumes both species at the base of the sulfate reduction zone at a rate nearly equivalent to the diffusive sulfate flux. In contrast, because the oxidation of organic matter by sulfate reduction above the SMT (i.e., organoclastic SR) is one of several possibilities that can impart curvature on the sulfate profile, it is not possible to infer AOM from nonlinear pore water concentration profiles (Claypool et al., 2006). Under such circumstances, ex-situ rate measurements of sulfate reduction and anaerobic oxidation of methane may be used to determine the relative contribution of each pathway in the depth integrated sulfate reduction budget (Orcutt et al., 2005; Joye et al., 2004; Treude et al., 2005). However, the effectiveness of this approach is limited because ex-situ AOM rate measurements most likely underestimate the in-situ rates (Niemann et al., 2006). Alternatively, since organoclastic SR produces 2 moles of alkalinity (as bicarbonate) for each mole of sulfate consumed and AOM produces 1 mole of alkalinity for each mole of sulfate consumed, the relative 
a

KC03-05

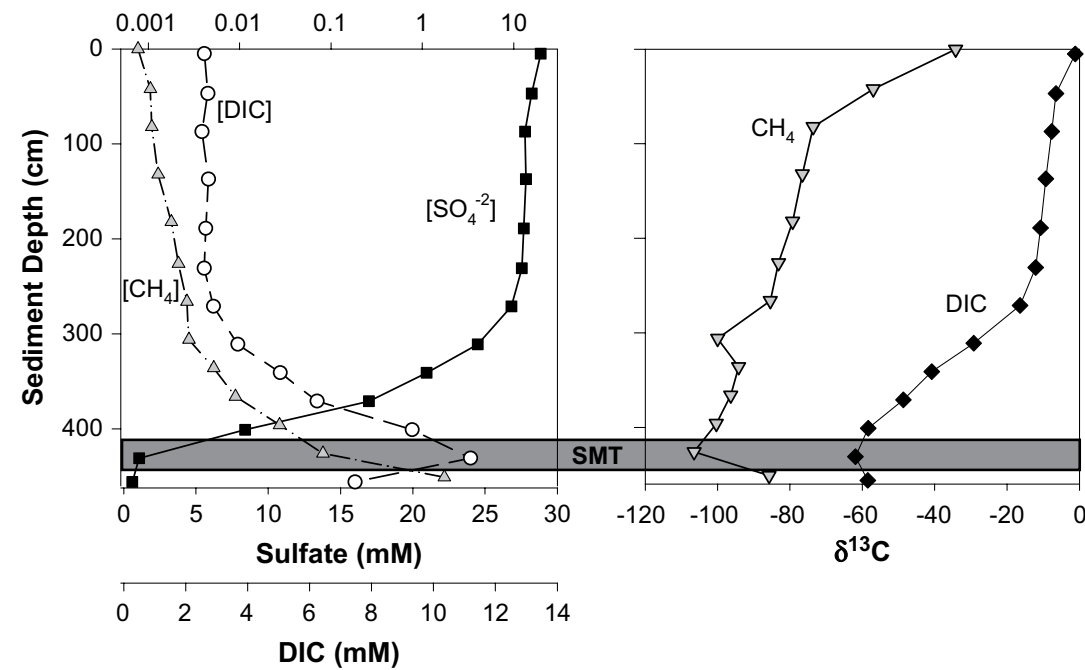

b

KC03-07
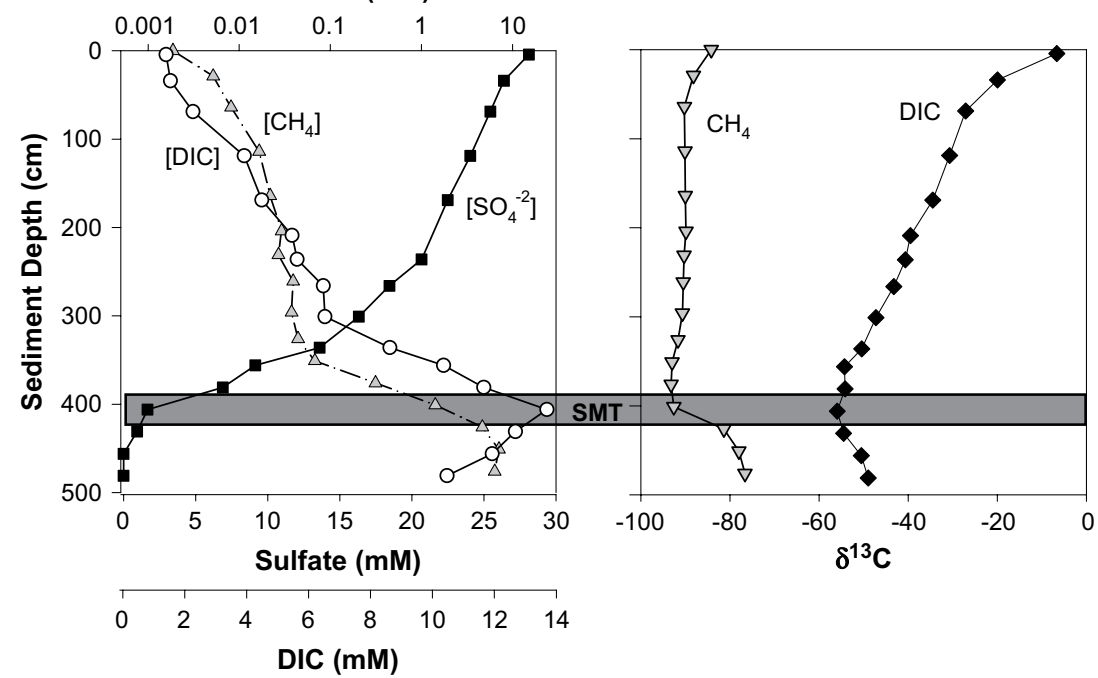

C

KC03-19

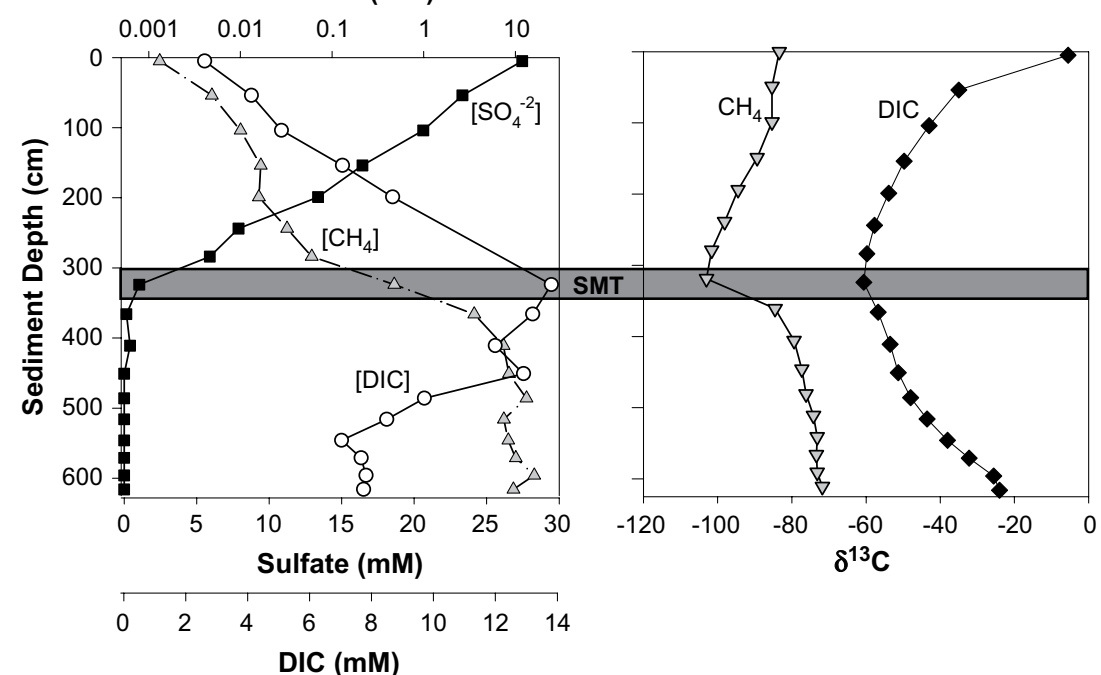

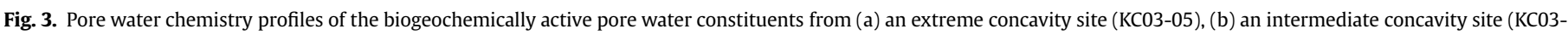

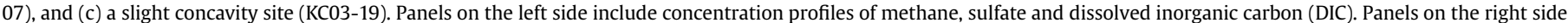
are stable carbon isotope data $\left(\delta^{13} \mathrm{C}\right)$ for the DIC and methane. The sulfate-methane transition (SMT) is indicated in gray shading for each core. 
Table 2

Molecular and isotopic properties of void gas samples from KC03-19

\begin{tabular}{llllll}
\hline Sediment depth $(\mathrm{cm})$ & $C_{1}(\%)$ & $C_{2}(\%)$ & $C_{3}(\%)$ & $C_{1} / C_{2+}$ & $\delta^{13} \mathrm{C}$ \\
\hline 477 & 99.99 & 0.01 & $<0.001$ & 7160 & -73.4 \\
526 & 99.98 & 0.02 & nd & 4690 & -76.2 \\
581 & 99.98 & 0.02 & nd & 5717 & -76.1 \\
611 & 99.99 & 0.01 & nd & 9288 & -74.9 \\
\hline
\end{tabular}

contributions of AOM and organoclastic SR may be determined by plotting the change in concentration of sulfate against the change in alkalinity that has been corrected for losses from carbonate precipitation and alterations due to brine influx (Claypool et al., 2006; Kastner et al., 2008). A slope of 2 for corrected alkalinity change versus sulfate concentration change indicates organoclastic SR is the primary pathway, whereas a slope of 1 indicates AOM is the primary pathway. Actual slopes determined by linear regression will range between 1 and 2, which reflects the relative contribution from each pathway. However, the data required for correcting the alkalinity data $\left(\mathrm{Mg}^{2+}\right.$ and $\left.\mathrm{Ca}^{2+}\right)$ were not collected in this study; meaning that a comparative analysis is not possible.

All of the pore water sulfate profiles measured in the 18 piston cores we collected at Keathley Canyon (Fig. 1) are nonlinear (Fig. 2a). Numerous physical, chemical, and biological mechanisms might explain the nature of this nonlinearity: (a) bioirrigation by macrobenthic organisms; (b) in-situ production of sulfate from sulfide oxidation; (c) downwelling (recharge) driven by thermal and/or chemical convection; (d) increased methane flux; (e) nonsteady state deposition; and (f) mass (instantaneous) deposition (e.g., Fossing et al., 2000; Hensen et al., 2003; Hutchinson et al., in press; Wilson and Ruppel, 2007). The net effect of any of these processes is an excess of sulfate relative to a linear gradient. Among the possible sources of excess sulfate, only sulfide oxidation can generate sulfate in-situ. However, sulfide was virtually absent (and therefore unavailable for oxidation to sulfate) in the upper $3 \mathrm{~m}$ of the cores with extreme concavity (Fig. 2d). Therefore, a physical mechanism is most likely responsible for the excess sulfate. Constraining that mechanism is the subject of another investigation and beyond the scope of this study.

\subsection{Chloride as conservative tracer for delineating biogeochemical processes}

To differentiate the effects of physical mixing, AOM, and organoclastic SR in pore water systems with concave pore water concentration profiles, we utilize dissolved chloride as a chemically conservative tracer known to be unaffected by diagenetic processes. Dissolved chloride concentrations are influenced by mineral dehydration and hydration, salt dissolution, and gas hydrate dissociation or formation in marine sediments (Kastner et al., 1991; Ussler and Paull, 2001; Torres et al., 2004; Reitz et al., 2007). However, at the shallow sediment depths $(<10 \mathrm{~m})$ investigated in this study burial metamorphism is not expected, and we observe no low or high chloride anomalies indicative of gas hydrate dissociation or formation, respectively (Fig. 2b). Therefore, conservative mixing between seawater and the basinal brine is most likely the only factor that influences the distribution of chloride within the cores. A similar mixing effect would be expected for the biogeochemically reactive dissolved pore water constituents (e.g., sulfate and DIC), making it possible to differentiate the relative influences of physical mixing and in-situ reactions on the distribution of the reactive pore water constituents.

In estuarine systems, conservative mixing diagrams are often used to differentiate the relative roles of physical and reactive processes in controlling the distribution of biogeochemically reactive chemical species along the estuarine salinity gradient
(Cifuentes and Eldridge, 1998; Chanton and Lewis, 1999; Coffin and Cifuentes, 1999; Kaldy et al., 2005). Production within the estuary yields an excess of the product relative to conservative mixing between the freshwater and ocean endmembers, while consumption results in depletion. Here, we apply this concept to the focus cores that represent the three characteristic types of pore water concentration profiles (Fig. 3) for the purpose of evaluating which sulfate reducing biogeochemical process(es) influenced the concentration of sulfate and DIC, and the $\delta^{13} \mathrm{C}$ of the DIC between the sediment-water interface and the SMT.

Conservative mixing of sulfate or DIC between the pore water in seafloor sediments and the pore water brine at the SMT was calculated using the approach of Fry (2002) modified to account for the high salinity pore water:

$C_{\text {mix }}=f_{\mathrm{B}} C_{\mathrm{B}}+\left(1-f_{\mathrm{B}}\right) C_{\mathrm{S}}$.

Here $C$ denotes concentration of the relevant species and subscripts mix, $B$, and $S$ represent the conservative pore water mixture at the desired depth, the pore water brine at the SMT, and the pore water from the sample obtained closest to the seafloor, respectively. In this case, brine refers to any pore water with salinity elevated above that of seawater. In Eq. (3), $f_{\mathrm{B}}$ is the fraction of the brine endmember present in the mixture calculated from the chloride concentration:

$f_{\mathrm{B}}=\frac{\left[\mathrm{Cl}^{-}\right]_{\mathrm{S}}-\left[\mathrm{Cl}^{-}\right]_{\text {mix }}}{\left[\mathrm{Cl}^{-}\right]_{\mathrm{S}}-\left[\mathrm{Cl}^{-}\right]_{\mathrm{B}}}$,

where $\left[\mathrm{Cl}^{-}\right]$denotes chloride concentrations, and the subscripts are the same as in Eq. (3).

Using Eqs. (3) and (4), we calculate the degree of conservative mixing of sulfate and of DIC, adopting as endmember concentrations the values measured in the sample obtained nearest the seafloor and within the SMT. The large chloride concentration differences between the near-seafloor endmember and brine SMT endmember (Fig. 3) permits application of the method over a vertical length scale of meters, in contrast to a horizontal length scale of kilometers typical of estuaries. In-situ production of a chemical species produces values plotting above the conservative mixing line (a positive excursion), whereas consumption yields results that lie below the mixing line (a negative excursion). Deviations from simple mixing owing to sulfate reduction would produce sulfate concentrations below and DIC concentrations above the conservative mixing line.

Based on the results shown in Fig. 4a, analysis of the concentration data for KC03-05 (Fig. 3a), a core characterized by extreme concavity in the pore water profiles (Fig. 2), yields no evidence for sulfate reduction and DIC production above the SMT. The absence of evidence for sulfate reduction suggests that the concavity of the pore water profiles is principally the result of a physical process. For cores KC03-07 (Fig. 3b; moderately concave) and KC03-19 (Fig. 3c; slightly concave), some negative sulfate excursions and positive DIC excursions consistent with in-situ sulfate consumption and DIC production were observed in the mixing diagrams (Fig. $4 \mathrm{~b}$ and c).

$\delta^{13} \mathrm{C}$-DIC conservative mixing diagrams (Fig. $4 \mathrm{~b}$ and $\mathrm{c}$ ) are used to determine if the origin of the excess DIC is organoclastic SR or AOM. Conservative mixing of $\delta^{13} \mathrm{C}$ for the DIC was calculated using the method of Chanton and Lewis (1999), also adapted for a high salinity pore water system (Eq. (5)):

$\delta_{\text {mix }}=\frac{f_{\mathrm{B}} C_{\mathrm{B}} \delta_{\mathrm{B}}+\left(1-f_{\mathrm{B}}\right) C_{\mathrm{S}} \delta_{\mathrm{S}}}{C_{\text {mix }}}$

Here, the subscripts are the same as in previous equations, and $\delta$ denotes $\delta^{13} \mathrm{C}$ values of the DIC components. Because the brine 
a

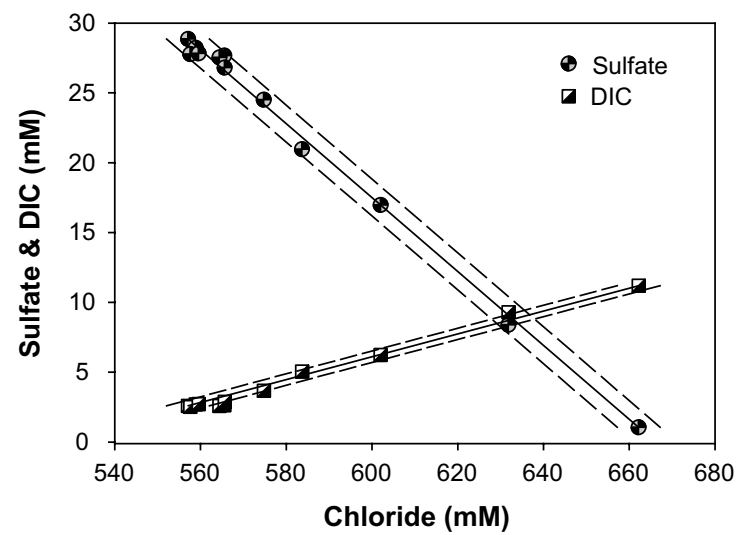

KC03-05

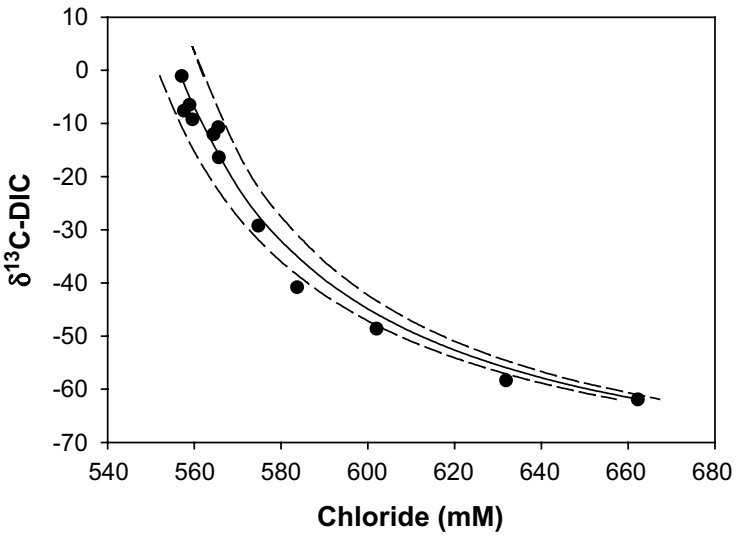

\section{KC03-07}
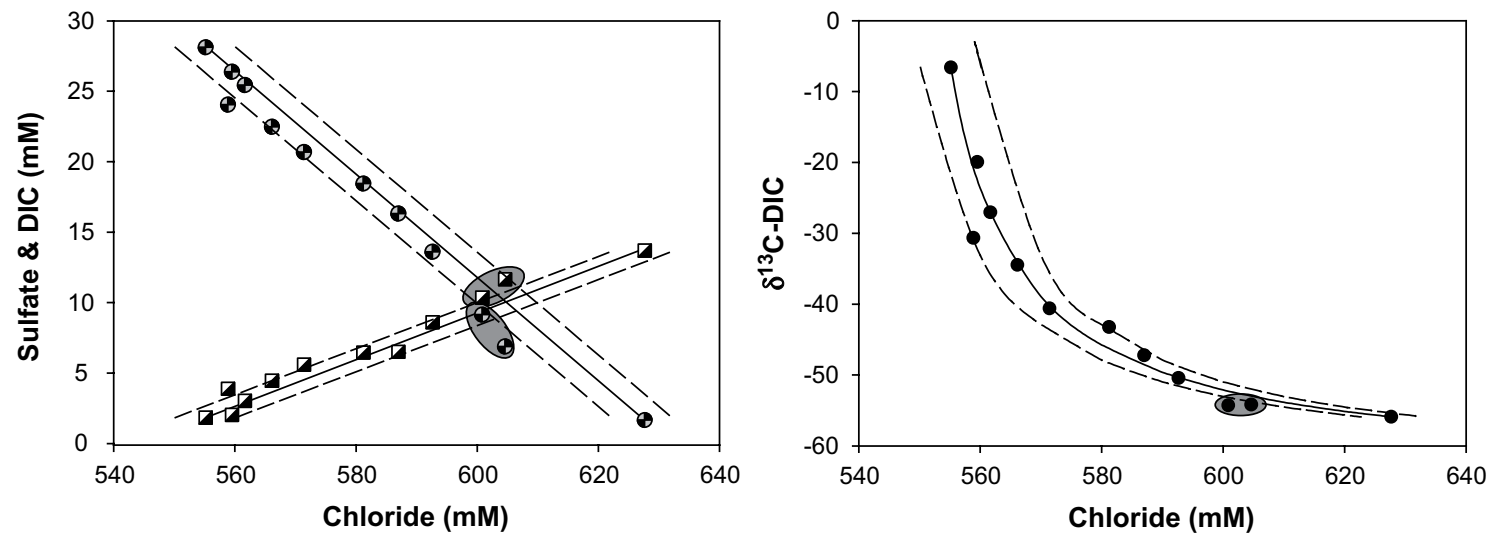

C

KC03-19
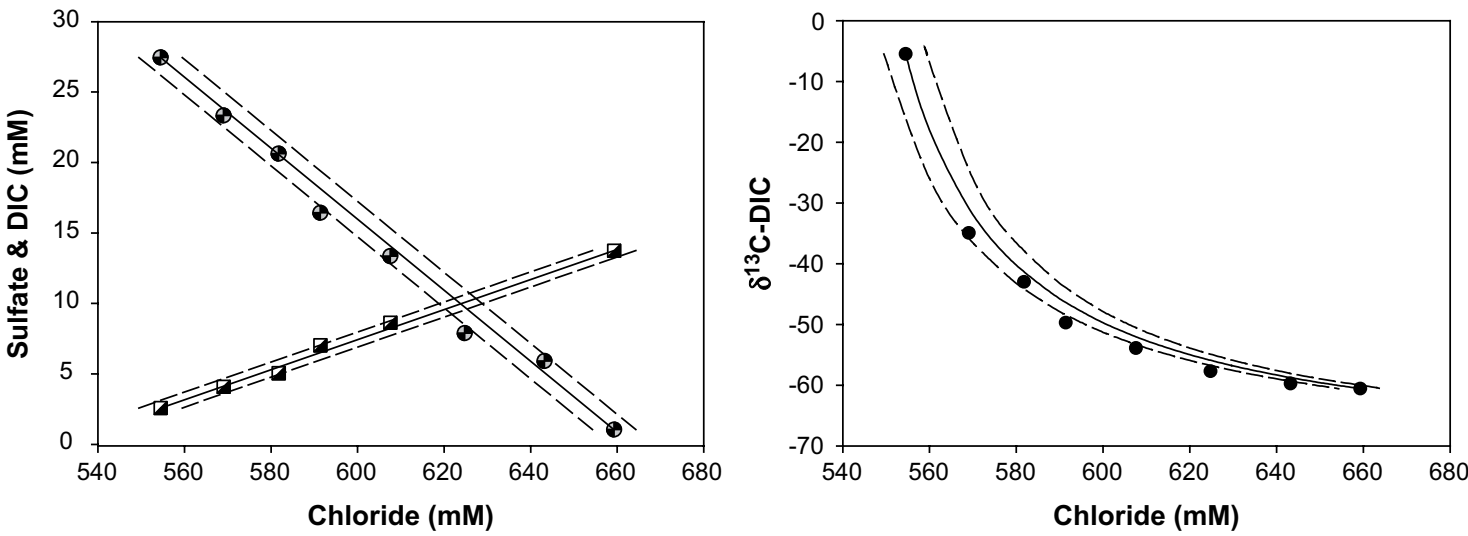

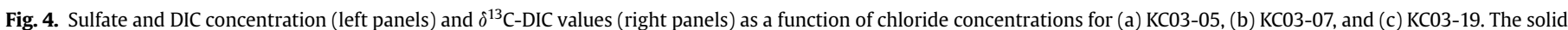

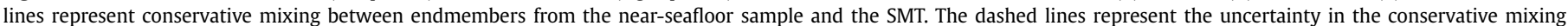

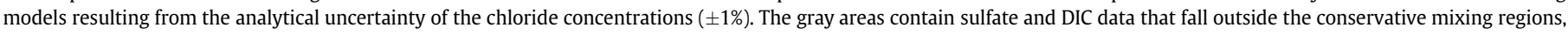
as discussed in the text.

endmember contained more DIC than the near-seafloor samples, conservative mixing of the isotope ratios is expected to produce a non-uniform (nonlinear) pattern of $\delta^{13} \mathrm{C}$ as a function of depth.

DIC produced from organoclastic SR would reflect the $\delta^{13} \mathrm{C}$ of the sediment organic matter, which ranges from approximately $-22 \%$ to $-26 \%$ in this region of the northern Gulf of Mexico (Jasper and Gagosian, 1989). On the other hand, DIC produced from $\mathrm{AOM}$ would have $\delta^{13} \mathrm{C}$ similar to that of the ${ }^{13} \mathrm{C}$-depleted methane. Two horizons immediately above the SMT in core
KC03-07 displayed slightly positive DIC excursions and slightly negative sulfate excursions where the $\delta^{13} \mathrm{C}$ of the DIC deviates from conservative mixing (shaded areas in Fig. 4b). Furthermore, the $\delta^{13} \mathrm{C}$ values are more ${ }^{13} \mathrm{C}$-depleted than the organic matter, which indicates the source of the ${ }^{13} \mathrm{C}$-depleted DIC source above the SMT is AOM. Ex-situ AOM rates reported from other studies confirm that, while AOM rates are usually greatest at a specific sediment horizon, AOM may occur over a 1-2 m depth interval near the SMT (Orcutt et al., 2005; Treude et al., 2005; Niemann et al., 2006). 
The fraction of the excess DIC potentially produced by AOM at the depths where the negative isotope excursions occurred $\left(f_{\mathrm{AOM}}\right)$ in $\mathrm{KCO3-07}$ was calculated from an isotope mass balance equation:

$f_{\mathrm{AOM}}=\frac{\delta_{\mathrm{PW}}-\delta_{\mathrm{mix}}}{\delta_{\mathrm{CH}_{4}}-\delta_{\mathrm{mix}}}$

where $\delta_{\mathrm{PW}}, \delta_{\text {mix }}$, and $\delta_{\mathrm{CH}_{4}}$ are $\delta^{13} \mathrm{C}$ values of the measured pore water DIC (approximately $-52.6 \%$ ), the conservatively mixed DIC (calculated from Eq. (5), and methane from that depth (approximately $-93 \%$ ), respectively. The estimated excess DIC produced by AOM at those depths was from $3 \%$ to $5 \%$ of the total DIC. Thus, AOM was the dominant biogeochemical pathway in this system, and it occurred predominantly within the horizon delineated as the SMT.

We note that the interpretation of the $\delta^{13} \mathrm{C}$-DIC data does not account for the carbon isotope fractionation that would result from faster diffusion of DIC with ${ }^{12} \mathrm{C}$ than that with ${ }^{13} \mathrm{C}$ (e.g., O'Leary, 1984; Alperin et al., 1988). To date, no theory can robustly determine these differential diffusivity values in pore fluids. Nonetheless, we expect the diffusivity variations attributable to isotope effects to be far less than uncertainties in diffusivities related to assumptions about porosities, tortuosity, and sediment temperatures and are confident that the interpretations based on the conservative mixing approach provide fundamental insight into important biogeochemical processes.

\section{Conclusions}

Microbial methane is the dominant hydrocarbon source and substrate for AOM in the near-seafloor sediments of a large seafloor mound on the edge of a minibasin in Keathley Canyon lease block 151 in the northern Gulf of Mexico. AOM was identified from pore water chemistry depth profiles indicating consumption of methane and sulfate, and production of DIC with $\delta^{13} \mathrm{C}$ values as low as $-61.9 \%$ at the SMT. Methane $\delta^{13} \mathrm{C}$ values as low as $-106.5 \%$ at the SMT indicate coupling between AOM and methanogenesis. Extensive concavity in the pore water chemistry depth profiles prevented the distinction of AOM and organoclastic SR pathways on the basis of the concentration-depth profiles. To evaluate these potential sulfate sinks, the sulfate concentrations, DIC concentrations, and $\delta^{13} \mathrm{C}$-DIC values from three cores characterized by different degrees of concavity are evaluated relative to mixing diagrams calculated from the vertical distribution of the biogeochemically conservative tracer chloride. For the most part, sulfate and DIC mixed conservatively between the SMT and the sediment-water interface. AOM was the dominant SR pathway and occurred almost exclusively within the $\sim 10$ to $25 \mathrm{~cm}$ thick SMT. Organoclastic sulfate reduction was not detected by the mixing model approach within any cores. The application of a chloride-based conservative mixing model is an effective approach for constraining the active sulfate reduction pathways and the vertical extent of AOM in high salinity pore water systems. A similar approach may be applied to understand the cycling of other biogeochemically reactive pools (e.g., DOC) in AOM-dominated, high salinity pore water systems.

\section{Acknowledgements}

We thank the captain and crew of the R/V Gyre and members of KC03 Scientific Party, particularly K. Grabowski, B. Yoza, D. Knies, R. Kuraski, C. Dale, and D. Bean, for their effort in rapidly processing the cores. Exceptional technical support by R. Plummer and logistical support by A. Miller and T. Debattista are also appreciated. We thank L. Lapham for thoughtful discussions during the preparation of this manuscript, and C. Paull, W. Waite, J. Crusius, and an anonymous reviewer for valuable suggestions on the manuscript. This work was supported by DOE's National Energy Technology
Laboratory, the Office of Naval Research, and the Naval Research Laboratory. J.W.P was supported by a USGS Mendenhall Postdoctoral Research Fellowship Program during preparation of this manuscript.

\section{References}

Alperin, M.J., Reeburgh, W.S., Whiticar, M.J., 1988. Carbon and hydrogen isotope fractionation resulting from anaerobic methane oxidation. Global Biogeochem. Cycles 2, 279-288.

Blair, N.E., Aller, R.C., 1995. Anaerobic methane oxidation on the Amazon shelf. Geochim. Cosmochim. Acta 59, 3707-3715.

Boehme, S.E., Blair, N.E., Chanton, J.P., Martens, C.S., 1996. A mass balance of ${ }^{13} \mathrm{C}$ and ${ }^{12} \mathrm{C}$ in an organic-rich methane-producing marine sediment. Geochim. Cosmochim. Acta 60, 3835-3848.

Boetius, A., Ravenschlag, K., Schubert, C.J., Rickert, D., Widdel, F., Gieseke, A., Amann, R., Jorgensen, B.B., Witte, U., Pfannkuche, O., 2000. A marine microbia consortium apparently mediating anaerobic oxidation of methane. Nature 407, 623-626.

Borowski, W.S., Paull, C.K., Ussler III, W., 1996. Marine pore-water sulfate profiles indicate in situ methane flux from underlying gas hydrate. Geology 24, 655-658.

Borowski, W.S., Paull, C.K., Ussler III, W., 1997. Carbon cycling within the upper methanogenic zone of continental rise sediments: an example from the methane-rich sediments overlying the Blake Ridge gas hydrate deposits. Mar. Chem. 57, 299-311.

Bouma, A.H., Roberts, H.H., 1990. Northern Gulf of Mexico continental slope. GeoMar. Lett. 10, 177-181.

Brooks, J., Kennicutt II, M.C., Fay, R.R., McDonald, T.J., Sassen, R., 1984. Thermogenic gas hydrates in the Gulf of Mexico. Science 225, 409-411.

Chanton, J.P., Lewis, F.G., 1999. Plankton and dissolved inorganic carbon isotopic composition in a river-dominated estuary: Apalachicola Bay, Florida. Estuaries $22,575-583$

Cifuentes, L.A., Eldridge, P.M., 1998. A mass- and isotope-balance model of DOC mixing in estuaries. Limnol. Oceanogr. 43, 1872-1882.

Claypool, G.E., Kaplan, I.R., 1974. The origin and distribution of methane in marine sediments. In: Kaplan, I.R. (Ed.), Natural Gases in Marine Sediments. Plenum Press, New York, pp. 99-139.

Claypool, G.E., Threlkeld, C.N., 1983. Anoxic diagenesis and methane generation in sediments of the Blake Outer Ridge, DSDP Site 533, Leg 76. In: Sheridan, R.E., Gradstein, F.M. (Eds.), Initial Reports of the DSDP, vol. 76, pp. 391-402.

Claypool, G.E., Milkov, A.V., Lee, Y.-J., Torres, M.E., Borowski, W.S., Tomaru, H., 2006 Microbial methane generation and gas transport in shallow sediments of an accretionary complex, southern Hydrate Ridge (ODP Leg 204), offshore Oregon, USA. In: Tréhu, A.M., Bohrmann, G., Torres, M.E., Colwell, F.S. (Eds.), Proc. ODP Sci. Results, 204, pp. 1-52, doi:10.2973/odp.proc.sr.204.113.2006. College Station, TX, ODP.

Cline, J.D., 1969. Spectrophotometric determination of hydrogen sulfide in natural waters. Limnol. Oceanogr. 14, 454-458.

Coffin, R.B., Cifuentes, L.A., 1999. Stable isotope analysis of carbon cycling in the Perdido Estuary, Florida. Estuaries 22, 917-926.

Dickens, G., 2001. On the fate of past gas: what happens to methane released from a bacterially mediated gas hydrate capacitor? Geochem. Geophys. Geosys. 2, doi:10.1029/2000GC000131.

Fossing, H., Ferdelman, T.G., Berg, P., 2000. Sulfate reduction and methane oxidation in continental margin sediments influenced by irrigation (South-East Atlantic off Namibia). Geochim. Cosmochim. Acta 64, 897-910.

Fry, B., 2002. Conservative mixing of stable isotopes across estuarine salinity gradients: a conceptual framework for monitoring watershed influences on downstream fisheries production. Estuaries 25, 264-271.

Hensen, C., Zabel, M., Pfeifer, K., Schwenk, T., Kasten, S., Riedinger, N., Schulz, H.D. Boetius, A., 2003. Control of sulfate pore-water profiles by sedimentary events and the significance of anaerobic oxidation of methane for the burial of sulfur in marine sediments. Geochim.Cosmochim. Acta 67, 2631-2647.

Hinrichs, K.U., Boetius, A., 2002. The anaerobic oxidation of methane: new insights in microbial ecology and biogeochemistry. In: Wefer, G., Billett, D., Jorgensen, B. B., Schluter, M., van Weering, T. (Eds.), Ocean Margin Systems. Springer, pp. 457-477.

Hoehler, T.M., Alperin, M.J., Albert, D.B., Martens, C.S., 1994. Field and laboratory studies of methane oxidation in an anoxic marine sediment - evidence for a methanogen-sulfate reducer consortium. Global Biogeochem. Cycles 8, 451-463.

Hoehler, T.M., Borowski, W.S., Alperin, M.J., Rodriguez, N.M., Paull, C.K., 2000 Model, stable isotope, and radiotracer characterization of anaerobic methane oxidation in gas hydrate-bearing sediments of the Blake Ridge. In: Paull, C.K. Matsumoto, R., Wallace, P.J., Dillon, W.P. (Eds.), Proc. ODP Sci. Results, 164, pp. 79-85.

Hutchinson, D.R., Hart, P.E., 2004. Cruise report for G1-03-GM USGS gas hydrates cruise, R/V Gyre, 1-14 May 2003, Northern Gulf of Mexico. US Geological Survey Open File Report 03-474, 103 pp.

Hutchinson, D.R., Hart, P.E., Collett, T.S., Edwards, K.M., Twichell, D.C., Snyder, F. 2008. Geologic framework of the 2005 Keathley Canyon gas hydrate research well, northern Gulf of Mexico. Mar. Petr. Geol. 25, 906-918. 
Hutchinson, D.R., Hart, P.E., Ruppel, C.D., Snyder, F., Dugan, B., Seismic and therma characterization of a bottom simulating reflection in the northern Gulf of Mexico: Collett, T.S., Johnson, A., Knapp, C., Boswell, R. (Eds.)., Natural Gas Hydrates: Energy Resource Potential and Associated Geologic Hazards: AAPC Memoir 89 (on DVD), in press.

Jasper, J.P., Gagosian, R.B., 1989. Glacial-interglacial climatically forced $\delta^{13} \mathrm{C}$ variations in sedimentary organic matter. Nature 342, 60-62.

Joye, S.B., Boetius, A., Orcutt, B.N., Montoya, J.P., Schulz, H.N., Erickson, M.J., Lugo, S K., 2004. The anaerobic oxidation of methane and sulfate reduction in sediments from Gulf of Mexico cold seeps. Chem. Geol. 205, 219-238.

Kaldy, J.E., Cifuentes, L.A., Brock, D., 2005. Using stable isotope analyses to assess carbon dynamics in a shallow subtropical estuary. Estuaries 28, 86-95.

Kastner, M., Elderfield, H., Martin, J.B., 1991. Fluids in convergent margins: what do we know about their composition, origin, role in diagenesis, and importance for oceanic chemical fluxes. Phil. Trans. Roy. Soc. Lond. Ser. A: Math. Phys. Sci. 335, 243-259.

Kastner, M., Claypool, G.E., Robertson, G., 2008. Geochemical constraints on the origin of the pore fluids and gas hydrate distribution at Atwater Valley and Keathley Canyon, Northern Gulf of Mexico, Mar. Petr. Geol. 25, 860-872.

Kniemeyer, O., Musat, F., Sievert, S.M., Knittel, K., Wilkes, H., Blumenberg, M. Michaelis, W., Classen, A., Bolm, C., Joye, S., Widdel, F., 2007. Anaerobic oxidation of short-chain hydrocarbons by marine sulphate-reducing bacteria. Nature 449, 898-901, doi:10.1038/nature06200.

Lorenson, T.D., Claypool, G.E., Dougherty, J.A., 2008. Natural gas geochemistry of sediments drilled on the 2005 Gulf of Mexico JIP cruise. Mar. Petr. Geol. 25 873-883.

MacDonald, I.R., Guinasso Jr., N.L., Ackleson, S.G., Amos, J.F., Duckworth, R Sassen, R., Brooks, J.M., 1993. Natural oil slicks in the Gulf of Mexico visible from space. J. Geophys. Res. 98, 16,351-16,364.

MacDonald, I.R, Leifer, I, Sassen, R., Stine, P., Mitchell, R, Guinasso Jr., N., 2002 Transfer of hydrocarbons from natural seeps to the water column and atmosphere. Geofluids 2, 95-107.

MacDonald, I.R., Reilly Jr., J.F., Best, S.E., Venkataramaiah, R., Sassen, R. Guinasso Jr., N.L., Amos, J., 1996. Remote sensing inventory of active oil seeps and chemosynthetic communities in the northern Gulf of Mexico. In: Schumacher, D., Abrams, M.A. (Eds.), Hydrocarbon Migration and its Nearsurface Expression. AAPG Memoir 66, pp. 217-237.

Milkov, A.V., 2005. Molecular and stable isotope compositions of natural gas hydrates: a revised global dataset and basic interpretations in the context of geological settings. Org. Geochem. 36, 681-702.

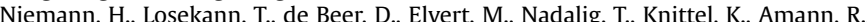
Sauter, E.J., Schluter, M., Klages, M., Foucher, J.P., Boetius, A., 2006. Novel microbial communities of the Haakon Mosby mud volcano and their role as a methane sink. Nature 443, 854-858.

Niewohner, C., Hensen, C., Kasten, S., Zabel, M., Schulz, H.D., 1998. Deep sulfate reduction completely mediated by anaerobic methane oxidation in sediments of the upwelling area off Namibia. Geochim.Cosmochim. Acta 62, 455-464

O'Leary, M.H., 1984. Measurement of the isotope fractionation associated with diffusion of carbon dioxide in aqueous solution. J. Phys.Chem. 88, 823-825.

Orcutt, B., Boetius, A., Elvert, M., Samarkin, V., Joye, S.B., 2005. Molecular biogeochemistry of sulfate reduction, methanogenesis and the anaerobic oxidation of methane at Gulf of Mexico cold seeps. Geochim.Cosmochim. Acta 60 4267-4281.

Orphan, V.J., House, C.H., Hinrichs, K.U., McKeegan, K.D., Delong, E.F., 2001 Methane-consuming archaea revealed by directly coupled isotopic and phylogenetic analysis. Science 293, 484-487.

Paull, C.K., Lorenson, T.D., Borowski, W.S., Ussler, W., Olsen, K., Rodriguez, N.M. 2000. Isotopic composition of $\mathrm{CH}_{4}, \mathrm{CO}_{2}$ species, and sedimentary organic matter within samples from the Blake Ridge: gas source implications. In:
Paull, C., Matsumoto, R., Wallace, P.J., Dillon, W.P. (Eds.), Proc. ODP Sci. Res., 164, pp. 67-78.

Paull, C.K., Ussler III, W., Lorenson, T.D., Winters, W., Dougherty, J.A., 2005. Geochemical constraints on the distribution of gas hydrates in the Gulf of Mexico. Geo-Mar. Lett. 25, 273-280.

Peel, F.J., Travis, C.J., Hossack, J.R., 1995. Genetic structural provinces and salt tectonics of the Cenozoic offshore U.S. Gulf of Mexico; a preliminary analysis. In: Jackson, M.P.A., Roberts, D.G., Snelson, S. (Eds.), Salt Tectonics. AAPG Memoir 65, pp. 153-175.

Plummer, R.E., Pohlman, J.W., Coffin, R.B., 2005. Compound specific stable carbon isotope analysis of low-concentration complex hydrocarbon mixtures from natural gas hydrate systems. EOS, Trans. AGU 86 (52) (Abstract OS43A 0608).

Reitz, A., Haeckel, M. Wallmann, K. Hensen, C. Heeschen, K., 2007. Origin of salt-enriched fluids in the northern Gulf of Mexico. Earth Planet. Sci. Lett. 259, 266-282.

Reeburgh, W.S., 1967. An improved interstitial water sampler. Limnol. Oceanogr. 12 163-165.

Roberts, H.H., Aharon, P., Carney, R., Larkin, J., Sassen, R., 1990. Sea floor responses to hydrocarbon seeps, Louisiana continental slope. Geo-Mar. Lett. 10, 232-243.

Roberts, H.H., Carney, R.S., 1997. Evidence of episodic fluid, gas, and sediment venting on the northern Gulf of Mexico continental slope. Econ. Geol. 92, 863-879.

Ruppel, C., Dickens, G.R., Castellini, D.G., Gilhooly, W., Lizarralde, D., 2005. Heat and salt inhibition of gas hydrate formation in the northern Gulf of Mexico. Geophys. Res. Lett. 32, L04625, doi:10.1029/2004GL021909.

Sager, W.W., MacDonald, I.R., Hou, R., Bryant, W.R., Doyle, E.H., 2004. Side-scan sonar imaging of hydrocarbon seeps on the Louisiana continental slope. AAPG Bull. 88, 725-746.

Sassen, R., Milkov, A.V., Ozgul, E., Roberts, H.H., Hunt, J.L., Beeunas, M.A., Chanton, J. P., DeFreitas, D.A., Sweet, S.T., 2003. Gas venting and subsurface charge in the Green Canyon area, Gulf of Mexico continental slope: evidence of a deep bacterial methane source? Org. Geochem. 34, 1455-1464.

Sassen, R., Sweet, S.T., Milkov, A.V., DeFreitas, D.A., Kennicutt II, M.C., Roberts, H.H., 2001. Stability of thermogenic gas hydrate in the Gulf of Mexico: constraints on models of climate change. In: Paull, C.K., Dillon, W. (Eds.), Natural Gas Hydrates; Occurrence, Distribution and Detection. American Geophysical Union Monograph 124, Washington, DC, pp. 131-143.

Sloan, E.D., 1998. Clathrate Hydrates of Natural Gases. Marcel Dekker, New York, $705 \mathrm{pp}$.

Torres, M.E., Wallmann, K., Trehu, A.M., Bohrmann, G., Borowski, W.S., Tomaru, H., 2004. Gas hydrate growth, methane transport, and chloride enrichment at the southern summit of Hydrate Ridge, Cascadia margin off Oregon. Earth Planet. Sci. Lett. 226, 225-241.

Treude, T., Niggemann, J., Kallmeyer, J., Wintersteller, P., Schubert, C.J., Boetius, A., Jorgensen, B.B., 2005. Anaerobic oxidation of methane and sulfate reduction along the Chilean continental margin. Geochim. Cosmochim. Acta 69, 2767-2779.

Ussler III, W., Paull, C.K., 2001. Ion exclusion associated with marine gas hydrate deposits. In: Paull, C.K., Dillon, W. (Eds.), Natural Gas Hydrates; Occurrence, Distribution and Detection. American Geophysical Union Monograph 124, Washington, DC, pp. 41-51.

Valentine, D.L., Reeburgh, W.S., 2000. New perspectives on anaerobic methane oxidation. Environ. Microbiol. 2, 477-484.

Whelan, J.K., Eglington, L., Cathles, L.I., Losh, S.L., Roberts, H., 2005. Surface and subsurface manifestations of gas movement through a N-S transect of the Gulf of Mexico. Mar. Petr. Geol. 22, 479-497.

Whiticar, M.J., 1999. Carbon and hydrogen isotope systematics of bacterial formation and oxidation of methane. Chem. Geol. 161, 291-314.

Wilson, A., Ruppel, C., 2007. Salt tectonics and shallow subseafloor fluid convection: models of coupled fluid-heat-salt transport. Geofluids 7, 377-386.

Yamamoto, S., Alcauskas, J.B., Crozier, T.E., 1976. Solubility of methane in distilled water and seawater. J. Chem. Eng. Data 21, 78-80. 